\title{
FE3AL VE Tİ6AL4V ALAŞIMLARININ DİFÜZYON KAYNAĞI
}

\author{
Osman TORUN ${ }^{*}$, İbrahim ÇELIKKYÜREK² \\ ${ }^{1}$ Afyon Kocatepe Üniversitesi, Teknoloji Fakültesi, Mekatronik Mühendisliği, Afyonkarahisar. \\ ORCID No: http://orcid.org/0000-0003-4976-5533 \\ ${ }^{2}$ Eskișehir Osmangazi Üniversitesi, Mühendislik Fakültesi, Metalürji ve Malzeme Müh. Bölümü, Eskişehir. \\ ORCID No : : http://orcid.org/0000-0002-6081-0473
}

\begin{tabular}{|c|c|}
\hline Anahtar Kelimeler & Öz \\
\hline $\begin{array}{l}\text { Difüzyon kaynă̆ı, Ti6Al4V, } \\
\text { Fe3Al, SEM }\end{array}$ & 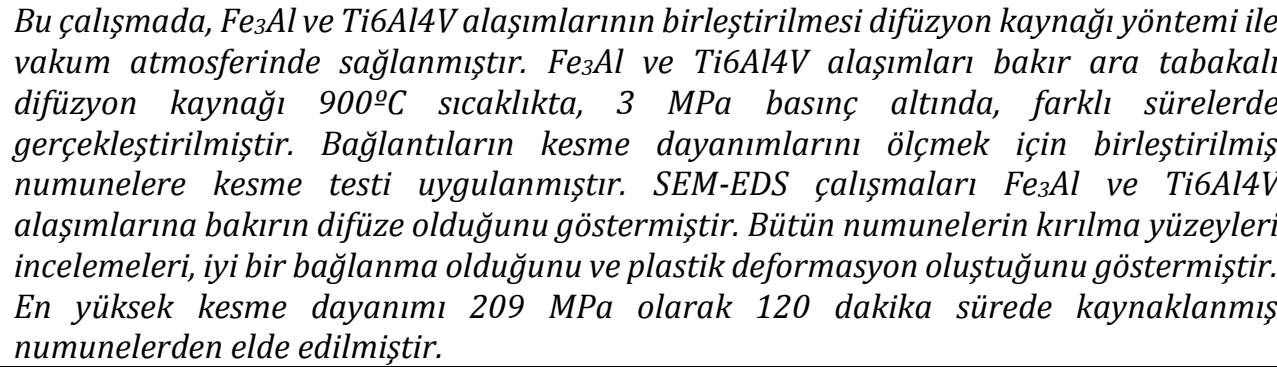 \\
\hline
\end{tabular}

\section{DIFFUSION WELDING OF FE 3 AL VE TI6AL4V ALLOYS}

\begin{tabular}{|c|c|}
\hline Keywords & Abstract \\
\hline $\begin{array}{l}\text { Diffusion welding, Ti6Al4V, } \\
\mathrm{Fe}_{3} \mathrm{Al}, \mathrm{SEM}\end{array}$ & $\begin{array}{l}\text { In this study, bonding of Fe } 3 \text { Al and Ti6Al4V alloys proved with diffusion bonding method } \\
\text { in vacuum atmosphere. Diffusion bonding of Fe } 3 \text { Al and Ti6Al4V alloys with copper } \\
\text { interlayer was carried out at } 900^{\circ} \mathrm{C} \text { for different times under } 3 \mathrm{MPa} \text {. Shear test was } \\
\text { applied to bonded samples to measure the shear strength of the welds. SEM-EDS studies } \\
\text { indicated diffusion of copper atoms to Fe }{ }_{3} A l \text { and Ti6Al4V matrix. Investigations of the } \\
\text { fracture surfaces of all samples showed the sign of good bonding with some plastic } \\
\text { deformation. The highest shear strength of } 209 \mathrm{MPa} \text { was obtained from samples bonded } \\
\text { for } 120 \text { minutes. }\end{array}$ \\
\hline Araștırma Makalesi & Research Article \\
\hline Başvuru Tarihi & Submission Date \\
\hline Kabul Tarihi & Accepted Date \\
\hline
\end{tabular}

\section{Giriş}

Titanyum ve alaşımlarının; kimya, endüstri, deniz ve uzay ile ilgili uygulamaların büyük bir bölümünde oldukça güvenilir ve ekonomik olduğu teknik açıdan tespit edilmiştir. Bu alaşımların kullanımı uzay, uçak, deniz ve otomobil sanayi alanlarında yoğunlașmıștır (Lauer ve diğ., 2001). Ti ve alaşımları yoğunluğunun düşük olması ve spesifik mukavemetleri nedeniyle havacılık uygulamalarında kendine oldukça geniş yer bulmuștur. Titanyumun bu üstün özellikleri sadece havacılık sanayinde değil, diğer birçok endüstri kolunda da kendisine önemli bir yer edinmesini sağlamıştır (Barış, 2007). Titanyum alaşımlarından yapılan malzemelerin uzun ömürlü olmaları, fiyat/kullanım ömrü açısından diğer malzemelerin önünde yer almaktadır. Titanyum ve alaşımlarının havacılıkta yaygın kullanım yerlerinden biri de gaz türbin motorlarıdır. Gaz türbin motorlarının ağırlıkça 1/3'ü titanyum alaşımlardan oluşmaktadır. Titanyum alaşımların uçak motorlarında kullanımı 1950'li yıllarda başlamıştır. İlk olarak kompresör kanatçıkları titanyumdan imal edilmeye başlanmıș, daha sonra kompresör disklerinin de titanyumdan üretimine geçilmiştir. Yakıt tasarrufu sağlayan ve çevreye daha az zarar veren araçlara olan talebin artması araçların ağırlığının hafiflemesi ve performansın arttırılmasını gerektirmiştir.

$\mathrm{Bu}$ noktada yüksek korozyon direnci ve güce sahip titanyum alaşımları başlıca tercih malzemesi olmuştur. Ancak titanyumun maliyeti arttırması otomotiv endüstrisinde daha yaygın olarak kullanılmasının önündeki en büyük engeldir (Takahashi, Fujı ve Yamashita, 2003). Öte yandan özellikle titanyumun çeliğe oranla çok daha düşük elastik modülüne ve düşük kayma modülüne sahip olması tercih sebebidir (Leyens ve Peters, 2003; Akagündüz, 2008). Alaşımsız titanyum ve alfa titanyum alaşımlarının tümü kaynak edilebilirdir.

\footnotetext{
*Sorumlu yazar; e-posta : otorun@aku.edu.tr
} 
Alfa beta titanyum alaşımı Ti6Al4V ve diğer zayıf beta kararlaştırıcı elementler içeren alaşımlar bile kaynak edilebilirdir (Barıș, 2007).

Düzenli metaller arası bileşikler yüksek sıcaklık kararlılı̆̆l, yüksek sürünme direnci, yüksek ergime noktası ve düşük yoğunluk nedeniyle yüksek sıcaklık uygulamaları için ilgi çekici malzemelerdir. Metaller arası bileşikler arasında alüminitlerin yüzeyde oluşan koruyucu film tabakasının oluşması nedeniyle oksidasyon direnci oldukça yüksektir (Deevi ve Swindeman, 1998; Pank, Nathal ve Koss, 1998). Fe3Al ve FeAl esaslı demir alüminitler yüksek sıcaklıkta yapısal eleman olarak kullanım için mükemmel aday malzemelerdir. $\mathrm{Bu}$ malzemelerin avantajları, yüksek sıcaklıkta yüksek oksidasyon ve sülfürizasyon direnci, düşük maliyet ve düşük yoğunluktur (Liu, Stringer, Mundy, Horton ve Angelini, 1997; Stoloff Liu ve Deevi, 2000; Torun, Çelikyürek ve Gürler, 2008). Ancak bu alaşımlar oda sıcaklığında düşük sünekliğe ve yüksek sıcaklıkta düşük sürünme direncine sahiptirler (Stoloff, 1998).

Difüzyon kaynağı; yüksek sıcaklıkta belirli bir basınç altında temas eden yüzeylerin birleştirilmesiyle meydana gelen bir katı hal kaynak işlemidir (Torun, Karabulut, Baksan ve Çelikyürek, 2008). Difüzyon kaynağı iki karakteristik adımdan oluşur; birincisi yüzeylerin temasının sağlanması, ikincisi temas eden yüzeylerde metalik bağlanmanın tamamlanması. Sıcaklık, süre, basınç, metalürjik etkiler, yüzey hazırlama ve ara tabaka kullanımı, difüzyon kaynağının kalitesini belirleyen en önemli parametrelerdir. Ara tabaka bağlanmayı olumsuz yönde etkileyecek metalürjik problemleri minimize etmek için kullanılır. Ara tabakalar toz, saçmalı ve buharlaştırma ile kaplama, elektrolizle kaplama ve folyo gibi birçok formda kullanılabilir. Bu kaynak prosesi çelikler (Xueping, Xiaohui ve Zhiping, 2018)., alüminyum alaşımları, titanyum alaşımları, nikel alaşımları (Torun ve Çelikyürek, 2008)., magnezyum alaşımları (Varmazyar ve Khodaei, 2019) ve metallerarası bileșikler (Yang ve diğ., 2020) gibi birçok malzemede kullanılır. Literatür incelendiğinde, farklı malzemeler olan $\mathrm{Fe}_{3} \mathrm{Al}$ ve Ti6Al4V alaşımının difüzyon kaynağı üzerine ara tabaka kullanılarak herhangi bir çalışmaya rastlanmamıştır. Bu çalışmada, bu alaşımların bakır ara tabaka kullanılarak difüzyon kaynağı gerçekleştirilmiş, mikroyapı çalışmaları yapılmış ve mekanik özellikleri araştırılmıştır.

\section{Materyal ve Metot}

$\mathrm{Bu}$ çalışmada $\mathrm{Fe}_{3} \mathrm{Al}$ ve Ti6Al4V alaşımları difüzyon kaynağı yöntemiyle bakır ara tabaka kullanılarak birleştirilmiştir. Ti6Al4V özel bir firmadan temin edilmiştir. $\mathrm{Fe}_{3} \mathrm{Al}$ alaşımı vakum indüksiyon ocağında vakum atmosferinde ergitilmiş ve metal kalıba dökülmüştür. Tüm alaşım numuneler torna tezgâhında işlenerek difüzyon kaynağı işlemi için, $10 \mathrm{~mm}$ uzunluğunda ve $8 \mathrm{~mm}$ çapında hazırlanmıştır. Daha sonra numune yüzeyleri $\mathrm{SiC}$ zımpara ile zımparalanmıștır. Bu yüzeyler 6 mikron ve 1 mikron elmas pasta ile parlatılmış ve alkolle temizlenmiştir. Numunelerin birleștirilecek yüzeyleri elektroliz yöntemiyle yaklaşık 3-4 mikron kalınlıkta bakır ile kaplanmıștır. Kaplama işleminden sonra yüzeyleri tekrar alkolle temizlenmiştir. Temizlenen yüzeyler birbirine temas ettirilerek kaynak esnasında kaymayı önlemek için plastik bantla bantlanmıştır. Daha sonra kaynak işlemi için difüzyon kaynak fırınına yerleştirilmiştir. Kaynak işleminde önce difüzyon firını vakuma alınmıș, sonra argon gazı ile süpürülmüş ve tekrar vakuma alma işlemi yapılarak, vakum ortamında çalışılmıştır. Pilot deneylerde tespit edilen $3 \mathrm{MPa}$ lık yük uygulanarak, firın sıcaklığ $50^{\circ} \mathrm{C} /$ dak. hızıyla isıtılarak $900^{\circ} \mathrm{C}$ sıcaklığa getirilmiştir. Kaynak işlemleri $900^{\circ} \mathrm{C}$ 'de 30, 60 ve 120 dk. sürelerde difüzyon kaynak firınında (Şekil 1.) gerçekleștirilmiştir.

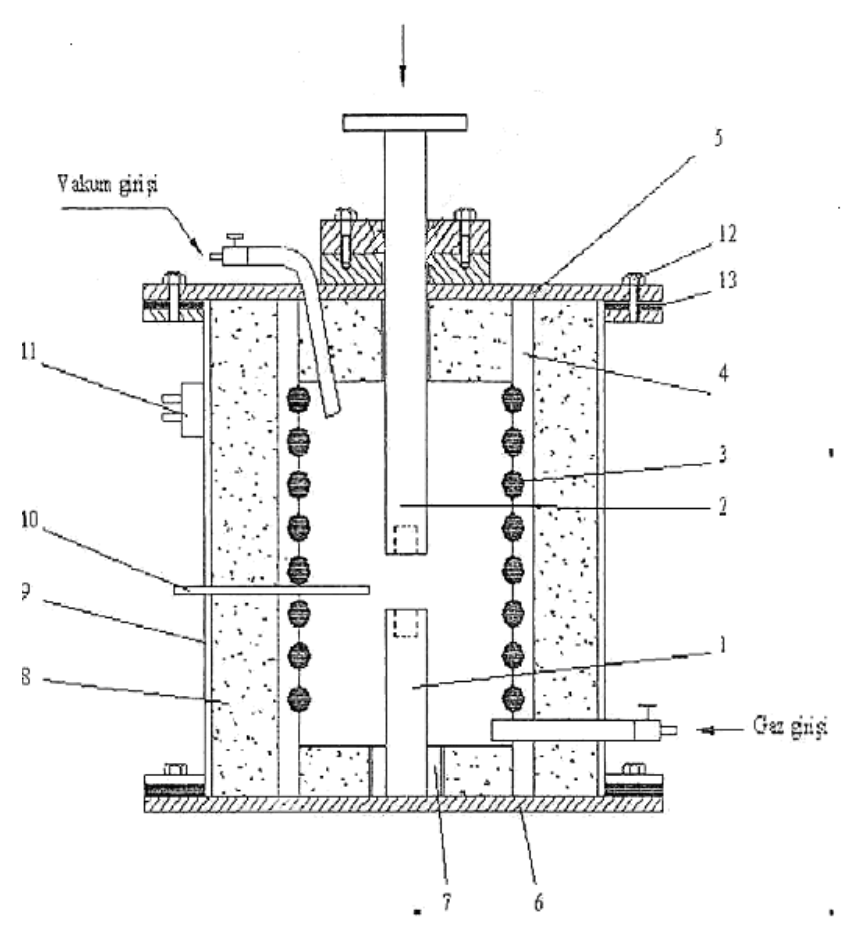

Şekil 1. Difüzyon firının kesit görünümü.

Daha sonra numuneler firın sıcaklığ $100-150^{\circ} \mathrm{C}$ düşünceye kadar firında, sonra serbest havada soğutulmuștur. Bu şekilde her bir kaynaklı numuneden 4 adet üretilmiştir. Numunelerden bir tanesi kaynaklı birleştirmeye dik olarak kesilerek, mikroyapı incelemeleri yapılmıştır. Diğer kaynaklı numunelere bağlanma mukavemetini belirlemek için Şekil 2' de gösterilen aparatla kesme testi uygulanmıștır. Ayrıca kaynaklı numunelerde kaynak merkezinden her iki matris malzemesine doğru mikrosertlik değerleri 
Future Tech FM 800 marka mikrosertlik cihazında 100 g yük ve 10 s kullanılarak ölçülmüştür. Mikroyapı çalışmaları için kaynak bölgesine dik olarak kesilen bakır ara tabakalı numuneler mikroyapı incelemesi için zımparalanmış ve-parlatılmıştır. Hazırlanan numuneler mikroyapı fotoğrafları JEOL 5600LV SEM cihazında çekilmiştir. Aynı cihaz ile numunelerin üzerinden farklı bölgelerden EDS analizleri yapılmıștır. Ayrıca, kesme makaslama testlerinden elde edilen kesme yüzeyleri de yine aynı cihazda incelenmiș, fotoğrafları çekilmiștir.

Bu çalışmada araştırma ve yayın etiğine uyulmuştur.

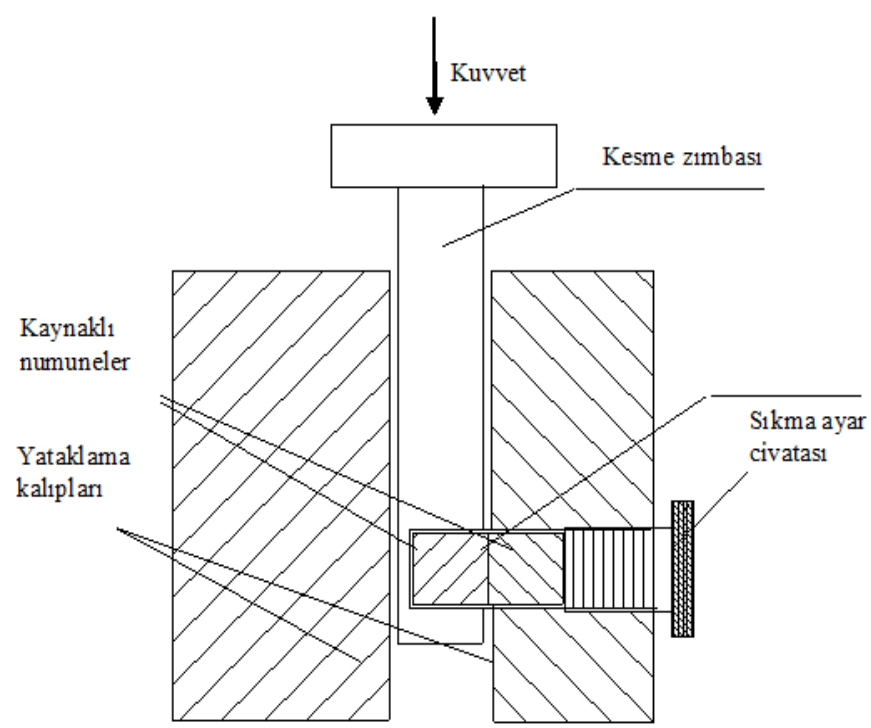

Şekil 2. Kesme Makaslama Test Aparatı ve Numunelerin Konumunun Şematik Görünümü

\section{Bulgular ve Tartışma}

Kaynaklı birleştirmesi yapılan numunelerin mikro yapıları taramalı elektron mikroskobu (SEM) ile incelenmiş ve mikroyapı fotoğrafları, Şekil 3' de verilmiştir. Ara tabaka kullanılmadan $\mathrm{Fe}_{3} \mathrm{Al}$ ve Ti6Al4V alaşımının difüzyon kaynağı yöntemi ile birleștirilmesi deney şartlarında gerçekleştirilememiştir. Ara tabaka malzemesi olarak bakır kullanılmış ve birleşme sağlanmıștır. Şekil 3' den de görüldüğü gibi 30, 60 ve 120 dakika sürelerde gerçekleștirilen bakır ara tabakalı tüm birleşimlerin boşluksuz ve iyi bir şekilde birleştiği görülmüştür.
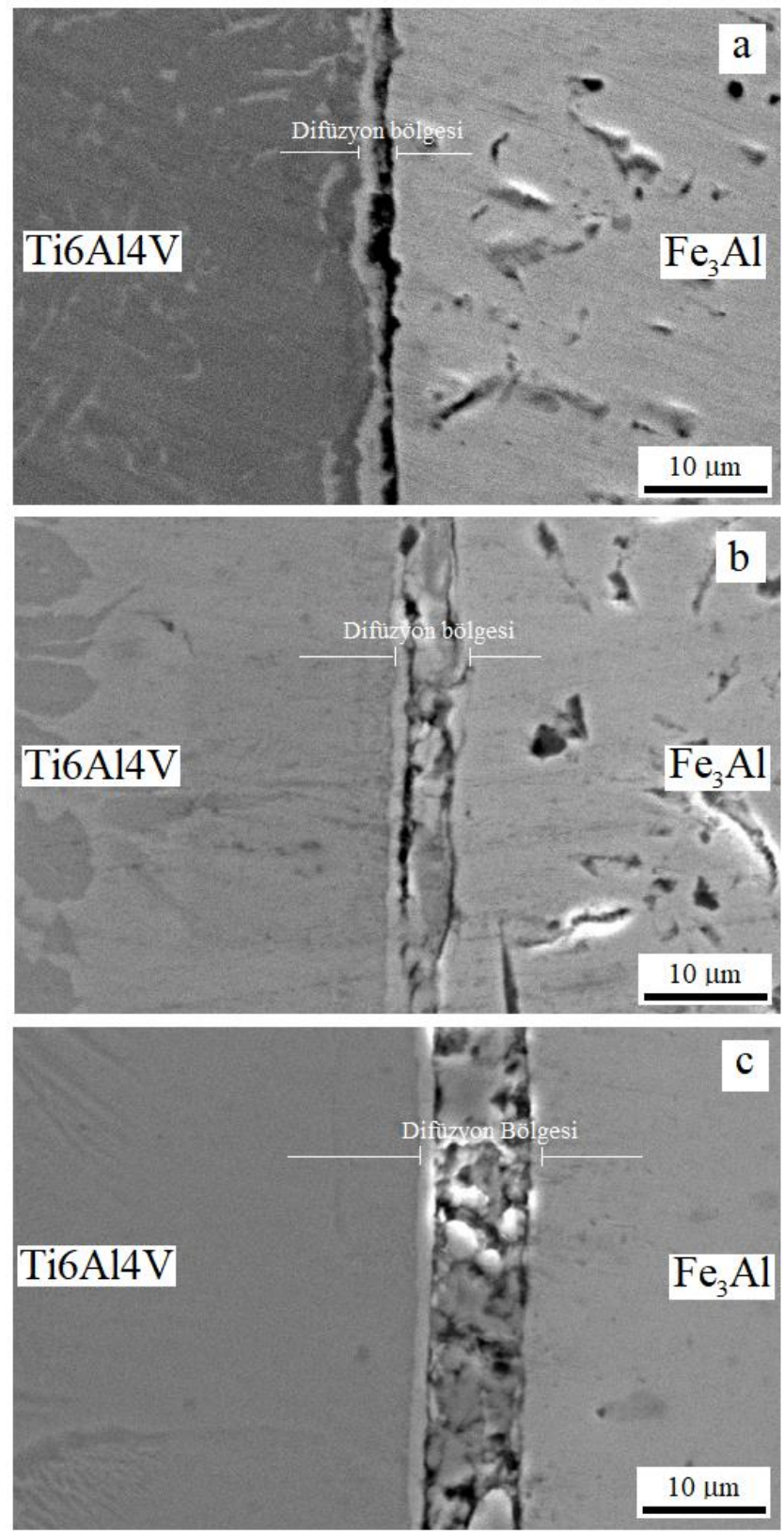

Șekil 3. Kaynaklanan Numunelerin SEM Fotoğrafları. a)30 dak. b) 60 dak. c) 120 dak.

Tüm kaynak sürelerinde bakır ara tabakalı numunelerin ara yüzeyde bir difüzyon bölgesi oluşmuştur. Kaynak süresindeki artışla difüzyon bölgesi genişlemiştir. Bu durum süredeki artışın atomlar arasındaki difüzyonu arttırdığını göstermektedir. Kaynaklı numunelerin difüzyon bölgesinde EDS analizleri yapılmış ve Şekil 4' te 120 dakika sürede kaynaklanan numunenin EDS analiz sonuçları verilmiştir. 
malzemelerin birleştirildiği düşünüldüğünde elde edilen değerler oldukça umut vericidir.

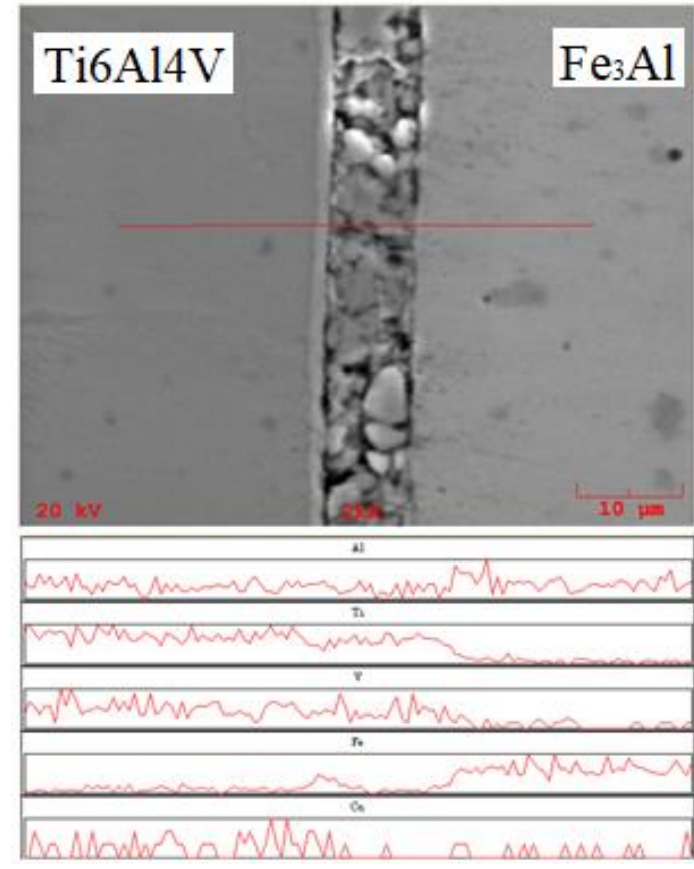

Şekil 4. 120 Dakika Sürede Kaynaklanan Numunenin EDS Analizi Sonuçları.

SEM-EDS analiz sonuçları kaynak esnasında ara tabaka olarak kullanılan $\mathrm{Cu}$ atomlarının matris yapılara, matris yapılardaki atomların bakır ara tabakaya difüze olduğunu göstermektedir. EDS analiz sonuçları dikkatle incelendiğinde bakır atomlarının Ti6Al4V alaşımı tarafına difüzyonunun $\mathrm{Fe}_{3} \mathrm{Al}$ tarafına göre difüzyonundan daha fazla miktarda olduğunu göstermektedir.

Kaynaklanmış numunelerin bağlanma mukavemetini belirlemek için her bir deney parametresi için üç adet numuneye kesme testi $0,1 \mathrm{~mm} / \mathrm{s}$ basma hızında yapılarak ortalaması alınmış ve elde edilen mukavemet değerleri Şekil 5.' te verilmiştir. Karşılaștırma yapmak amacıyla $\mathrm{Fe}_{3} \mathrm{Al}$ ve Ti6Al4V alaşımlarının kesme testileri de yapılmış ve kesme mukavemeti değerleri de verilmiştir. Kesme testi sonuçları, kaynak süresindeki artışla kaynak bölgesi mukavemetinde artış olduğunu göstermiștir. 30 dakika sürede kaynaklanan numunede $106 \mathrm{MPa}, 60$ dakikada kaynaklanan numunede $180 \mathrm{MPa}$ ve 120 dakika sürede kaynaklanan numunede $209 \mathrm{MPa}$ mukavemet değerleri elde edilmiştir. Süredeki artışla atomların difüzyonu kolaylaşmış ve difüze olan atom miktarı artarak daha geniş bir difüzyon bölgesi oluşmuştur. Süredeki artışla mukavemetin arttığı göz önüne alındığında, daha uzun kaynak sürelerinde bu difüzyon bölgelerinde daha mukavemetli fazlar oluştuğu düșünülebilir. Kaynaklı numunelerin kesme mukavemetleri alaşımlar ile kıyasladığında alaşımlardan yaklaşık \%50 daha düşüktür. Ancak farklı

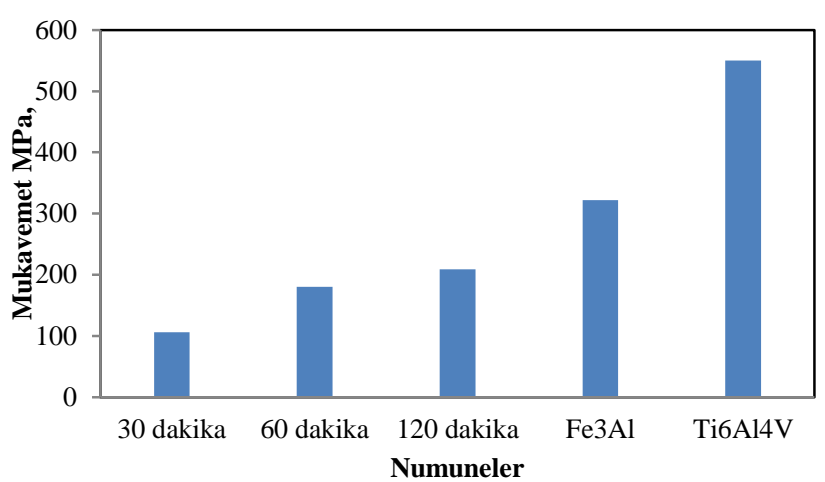

Şekil 5. Kaynaklı ve Orijinal Numunelerin Kesme Mukavemeti Değerleri.

Kaynaklı numunelerde kaynak merkezinden her iki matris malzemesine doğru mikrosertlik değerleri Şekil 6 'te verilmiştir.

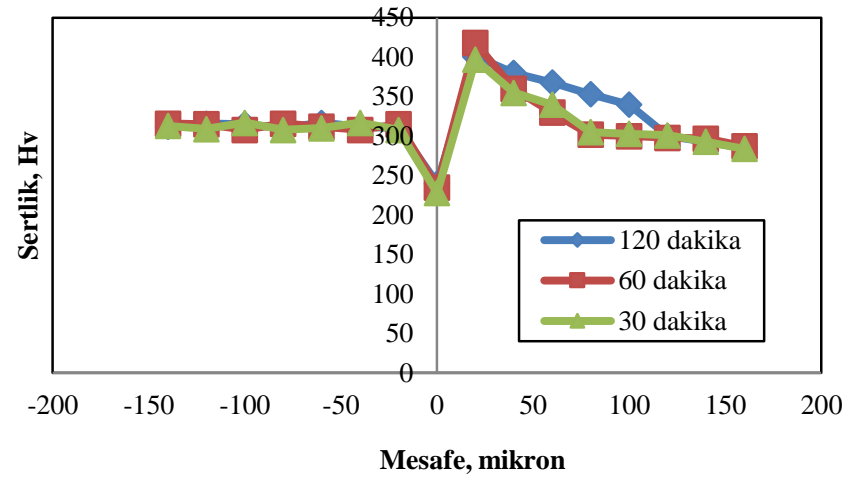

Şekil 6. Kaynaklı Numunelerin Kaynak Merkezinden Her İki Matrise Doğru Sertlik Değerleri.

Sertlik ölçüm sonuçları incelendiğinde, tüm kaynak süreleri için benzer bir sertlik dağılımı görülmüştür. $\mathrm{Fe}_{3} \mathrm{Al}$ tarafında sertlik değerlerinde bir değişim gözlenmezken, Ti6Al4V tarafında bir miktar sertlik artışı gözlenmiștir. Bu artış Ti6Al4V tarafına daha fazla miktarda difüze olan bakır atomlarının varlığından kaynaklanmaktadır. Bakır ara tabakalı kaynaklı numunelerin kesme yüzeyleri incelenmiş, SEM fotoğrafları çekilmiş ve yüzeylerden EDS analizleri alınmıştır. 120 dakika sürede kaynak yapılan numunenin kesme yüzeyi fotoğrafları ve EDS analizleri Şekil 7'de verilmiştir. 

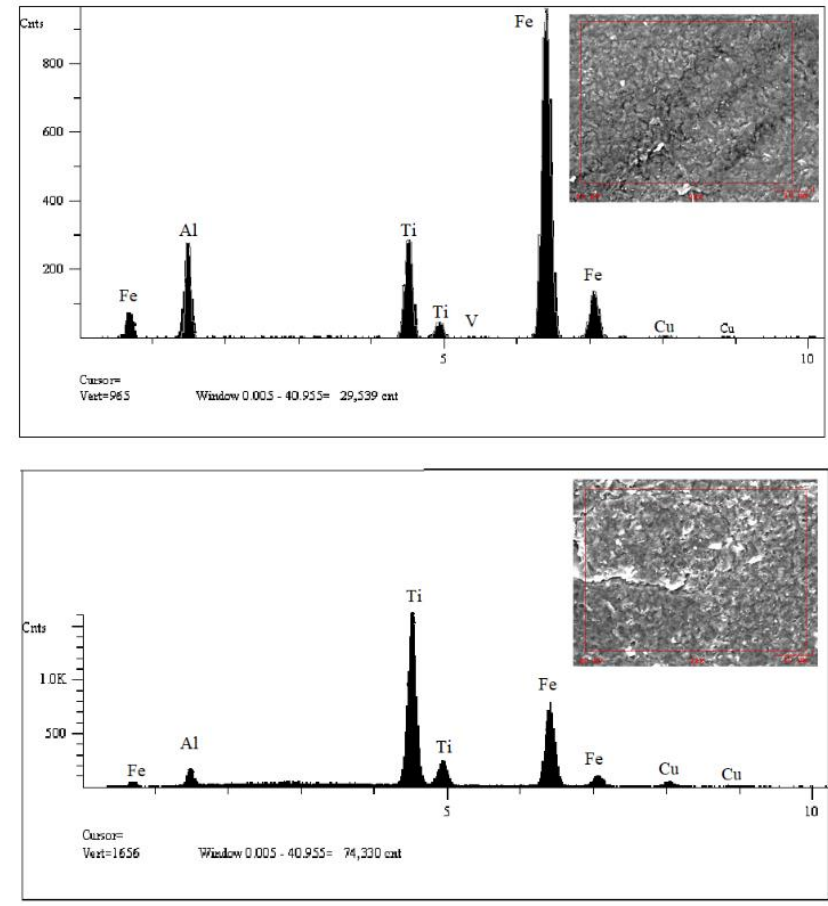

Şekil 7. 120 Dakika Sürede Kaynak Yapılan Numunenin Kesme Yüzeyi Fotoğrafları ve EDS Analizleri.

120 dakika sürede kaynaklanan numunelerin kesme yüzeyi fotoğrafları ve EDS analiz sonuçları incelendiğinde bakır ara tabaka ve matris yapılar arasındaki difüzyon açıkça görülmektedir. Element pikleri dikkatli incelendiğinde Ti6Al4V tarafında bakır atomlarının piklerinin daha belirgin olduğu görülmektedir. Bu sonuç bakır atomlarının Ti6Al4V tarafına $\mathrm{Fe}_{3} \mathrm{Al}$ tarafından daha fazla miktarda olduğunu onaylamaktadır. Ayrıca EDS sonuçları kesme testi esnasında kopmaların difüzyon bölgesinden gerçekleştiğini göstermişti

\section{Sonuçlar}

$\mathrm{Fe}_{3} \mathrm{Al}$ ve Ti6Al4V alaşımları bakır ara tabaka kullanılarak difüzyon kaynağı yöntemi ile vakum atmosferinde 30,60 ve 120 dakika sürelerde ve $900{ }^{\circ} \mathrm{C}$ başarılı bir şekilde boşluksuz, oksitsiz ve iyi bir şekilde birleştirilmiştir. Mikroyapı çalışmaları kaynak ara yüzeyinde difüzyon bölgesi oluştuğunu göstermiștir. Kaynak süresindeki artışla, malzeme ve bakır ara tabaka atomlarının daha fazla miktarda difüzyonuyla, difüzyon bölgesinin genişliği artmıştır. Bunun sonucunda difüzyon bölgesinde daha mukavemetli fazların oluştuğu tahmin edilmekte ve bu durumunda daha yüksek bir kesme mukavemeti sağladığı düşünülmektedir. Dolayısıyla, kaynak süresindeki artışla kaynak bölgesi kesme mukavemeti artmıştır. En yüksek kesme mukavemeti değeri 120 dakika sürede kaynaklanan numunelerde elde edilmiştir.

\section{Teşekkür}

$\mathrm{Bu}$ çalışma Afyon Kocatepe Üniversitesi Bilimsel Araştırma Projeleri Koordinasyon Birimi tarafından 17.MYO.04 nolu proje kapsamında desteklenmiştir.

\section{Araştırmacıların katkısı}

$\mathrm{Bu}$ araştırmada; Osman TORUN, bilimsel yayın araştırması, malzemelerin temini, deney sonuçların analiz edilmesi, makalenin genel kontrolünün yapılması; İbrahim ÇELIKKYÜREK, numunelerin üretilmesi, deneylerin yapılması konularında katkı sağlamışlardır.

\section{Çıkar Çatışması}

Yazar tarafından herhangi bir çıkar çatışması beyan edilmemiştir.

\section{Kaynaklar}

Akagündüz E. (2008). Isıl işlem görmüş Ti6Al4V alaşımının yüzey özelliklerinin mikroyapı ve yüzey çizilme dayanımları açısından incelenmesi ( Yüksek Lisans Tezi). Gebze Yüksek Teknoloji Enstitüsü, İstanbul.

Barış B., (2007). Ti6Al4V/304 L Malzeme çiftinin bakır ara tabaka kullanılarak difüzyon kaynağı ile birleştirilmesi (Yüksek Lisans Tezi). Fırat Üniversitesi, Fen Bilimleri Enstitüsü, Elazığ.

Deevi S.C.; \& Swindeman, R.W. (1998). Yielding, hardening and creep behavior of iron aluminides. Materials Science Engineering A, 258, 203-210. doi: https://doi.org/10.1016/S0921-5093(98)00935-6

Lauer G., Wiedmann Al-Ahmad M., Otten J. E., Schmelzeisen R. \& Schilli W. (2001). The titanium surface texture effects adherence and growth of human gingival keratinocytes and human maxillar osteoblastlike cells in vitro, Biomaterials, 22, 27992809. doi: http//doi.org/10.1016/s0142-9612(01) 00024-2

Leyens C. \& Peters M., (2003). Titanium and titanium alloys, Wiley VCH, Germany.

Liu, C.T., Stringer, J., Mundy, J.N., Horton, L.L. \& Angelini, P. (1997). Ordered intermetallic alloys: An assessment. Intermetallics. 5, 579-596. doi: https://doi.org/10.1016/S0966-9795(97) 00045-9

Pank, D.R., Nathal, M.V. \& Koss, D.A. (1998). High temperature ordered intermetallics Alloys III; Liu, C.T., Taub, A.I., Stoloff, N.S., Koch, C.C., Eds.; Materials Research Society: Pittsburgh, PA, USA, 561-565.

Stoloff, N.S. (1998). Iron aluminides: Present status and future prospects. Materials Science Engineering A 
258, 114. doi: https://doi.org/10.1016/S09215093(98) 00909-5

Stoloff, N.S., Liu, C.T. \& Deevi, S.C. (2000). Emerging applications of intermetallics. Intermetallics, 8, 13131320. doi: https://doi.org/10.1016/S09669795(00) 00077-7

Takahashi K., Fujı H. \& Yamashita Y. (2003). Application titanium and its alloys for automobile parts, Nippon Stell Tecnical Report, 2003, 70-75. doi: https://doi.org/10.1051/matecconf/ $\underline{202032102003}$

Torun O. ve Çelikyürek I., (2008). Diffusion bonding of nickel aluminide Ni75Al25 using a pure nickel interlayer. Intermetallics, 16, 406-409. doi: https://doi.org/10.1016/j.intermet. 2007.11.011

Torun O., Çelikyürek İ. ve Gürler R., (2008). Diffusion bonding of iron aluminide Fe72Al28 using a copper interlayer, Materials Characterization, 852- 856. doi: $\quad$ https://doi.org/10.1016/j.matchar. $\underline{2007.07 .001}$

Torun O., Karabulut A, Baksan B. ve Çelikyürek I., (2008). Diffusion bonding of AZ91 using a silver interlayer, Materials and Design 29, 2043-2046. doi: https://doi.org/10.1016/i.matdes. 2008.04.003

Xueping R., Xiaohui C. \& Zhiping X., (2018). Characterization and analysis of diffusion bonding process in a Cr25Ni7Mo4MnSi duplex stainless steel Journal of Manufacturing Processes, 34, Part A, 603613. doi:

https://doi.org/10.1016/i.jmapro.2018.07.005

Varmazyar J. \& Khodaei M., (2019). Diffusion bonding of aluminum-magnesium using cold rolled copper interlayer, Journal of Alloys and Compounds, Volume 773, 30, 838-843. doi: https://doi.org/10.1016/j.jallcom.2018.09.320

Yang Z.W., Lian J., Wang J., Cai X Q., Wang Y., Wang D.P, Wang Z. M. \& Liu C.Y., (2020). Diffusion bonding of $\mathrm{Ni} 3 \mathrm{Al}$-based alloy using a $\mathrm{Ni}$ interlayer. Journal of Alloys and Compounds, 819, $5 . \quad$ Doi : https://doi.org/10.1016/j.jallcom. 2019.153324 